\title{
SEMIOTIC ANALYSIS OF WOMAN IMAGE IN
}

\section{OUTDOOR ADVERTISEMENTS}

\begin{abstract}
Didem AŞCI ${ }^{1}$
ABSTRACT

The social role of woman shows an alteration parallel to time and culture. Today, in our country, the role of woman is defined as a kind mother, a good wife, attractive, and successful in business life. This affects the usage of woman image in outdoor advertisement. The woman is both the target group and the object of the advertisements. While the gender of woman influences the outdoor advertisements, the woman image in advertisements is influential on the woman image in society. In this research, the woman image in outdoor advertisement is analyzed by using semiotics. Visual and linguistic texts are analyzed together and the woman's role in social life and advertisements are studied and the relation between them is presented in outdoor advertisements where the woman image is being used. Generally, it can be stated that woman image in outdoor advertisement and the woman image in gender are two notions, which interact with each other and develop and change together as a result of this interaction.
\end{abstract}

Keywords: Woman Image, Gender, Outdoor Advertisement, Semiotics

${ }^{1}$ Öğretim Görevlisi Dr., Arel Üniversitesi, İletişim Fakültesi, Yeni Medya ve İletişim Bölümü, didemasci(at)arel.edu.tr 


\title{
AÇIKHAVA REKLAMLARINDA KADIN IMGESININ
}

\section{GÖSTERGEBILIMSEL ANALIZi}

\begin{abstract}
Kadın imgesi ve toplumsal cinsiyet kavramlarının toplumda uyandırdığı anlamlar gün geçtikçe değişmektedir. Kadının toplumsal rolü zamana ve kültüre paralel olarak değişiklik göstermektedir. Günümüzde ve ülkemizde kadının rolü iyi bir anne, iyi bir eş, bakımlı, çekici ve iş hayatında başarılı gibi farklı kavramlarla düşünülmektedir. Bu durum açıkhava reklamcılığında kadın imgesinin kullanımında da etkili olmaktadır. Kadın, reklamların hem hedef kitlesi hem de nesnesi durumundadır. Kadının toplumsal cinsiyet rolü açıkhava reklamlarını etkilerken, açıkhava reklamlarındaki kadın imgesi de toplumdaki kadın imgesi üzerinde etkili olmaktadır. Bu araştırmada reklam incelemede etkin bir yöntem olan göstergebilimsel analizden yararlanılarak açıkhava reklamlarında kadın imgesi incelenmektedir. Kadın imgesinin kullanıldığ 1 açıkhava reklamlarında görsel ve dilsel metinler bir arada ele alınmış, kadının toplumsal rolü ve açıkhava reklamlarındaki rolü incelenmiş ve bunların ilişkisi ortaya konmuştur. Genel olarak açıkhava reklamcılığındaki kadın imgesi ve toplumsal cinsiyetteki kadın imgesinin etkileşim içinde iki kavram olduğu söylenebilir.
\end{abstract}

Anahtar Kelimeler: Kadın İmgesi, Toplumsal Cinsiyet, Açıkhava Reklamcılığı, Göstergebilim 


\section{Introduction}

Communication is a notion, starting with the existence of humanity and in respect of area of utilization, outdoor advertisement is one of the oldest advertisement mediums. Elements that make up the advertisements, appears as the auditory and visual and linguistic elements. Advertisement is the one of the most important tool of visual communication with its visual and linguistic features.

Even though it is one of the oldest advertisement mediums, the outdoor advertisement could not develop for many years and remained in the background. By the people's role in society and as a result of technological developments, with the evolvement of areas of utilization and inevitability of this medium, which is open to creativity, the outdoor advertisement has developed and gained importance. Lately, the development of outdoor advertisement and the development of advertisement itself are in parallel situation. In these days, the number of consumers increases rapidly and people spending time outside effects this situation.

As for woman image, it has developed and gained importance in these times where the social roles change speedily. In recent years, the women have got out of the house and entered business life and gained a more efficient role in business life in Turkey. The most important reason that we see the woman image profusely in advertisements is that their new roles are different than their old roles, not only by substituting new roles but also developing their new roles with each day in Turkey. The old role of women as a good wife, a kind mother in society is making woman the receiver of advertisements. The target group of most of the advertisements is the women who are responsible for the shopping for the house, her family and herself. The role of woman in society makes her the element of advertisement. The woman, who is the consumer of the advertisement, wants to see herself with her designated roles in advertisements. These new roles present the image of woman who is successful in business life, beautiful and strong.

While making an advertisement analysis, the woman image, which has become the important element of advertisements, should be analyzed and its condition should be presented because the women image in advertisements and its interaction with its social role has become important with regards to its development in outdoor advertisements. The interaction of the woman image in society and the woman image in advertisements are inevitable.

In this research, the situation of woman image in outdoor advertisements are presented by using semiotic analysis method and results are evaluated through the 
women's role in both outdoor advertisements and gender mainstreaming by analyzing different sector advertisements.

This research based on the unpublished master thesis named "Semiotic Analysis of Woman Image: A Research in Today's İstanbul Outdoor Advertisements" written by Didem Aşc1 in 2012.

\section{Conceptual Framework}

Gender is one of the criteria that are used to group and diversify the individuals. Even though it is believed that all people are born equally and are equal before the law, there is the problem of gender apartheid. Today, gender mainstreaming presents itself subject to social, spiritual and cultural structuring, rather than biological differences. Gender is a notion, which is related to genetic, biologic, physiologic features that an individual indicates as a man or a woman (Üner, 2008: 6). The most critical point of gender regime is common beliefs and values related to womanhood and manhood. These show us hints to understand how the gender regime, which is a notional abstraction, is seen, how it is created and how it is established again. When we follow these hints, it is possible for us to make analysis about the potency mechanisms and the place of men and women in these mechanisms. The notion of gender mainstreaming, which has a characteristic extent connected with social structures and relations beyond the personal characteristics of gender, is the transformation of people who were born as "girls" and "boys" to "woman" and "man" as a result of many things in life (Bora and Üstün, 2005: 42). Gender mainstreaming is a notion that is related to the roles, tasks and responsibilities that the society give, how the society sees, perceives the individual and its expectations (Üner, 2008: 6).

Gender has become an important notion that determines the man and woman's social place. Gender has impact on such things as the toys that the man and woman play in childhood, their choice of profession, preferred sport and even their place in society. This effect is divisive rather than cohesive. In short, gender is the major element that defines the roles of man and woman in society. Media has an important role in enabling the equality of woman and man by means of including an equitable existence of woman and man. With portrayal of women in cliché roles in media and including the degrading woman image, continuity of the existing gender inequality in society is provided.

In recent years in Turkey, woman's appearance in public domain and its abandonment the private domain is observed. Socio-economically, the "modern" 
woman image, which gradually gains an appearance in public domain, is increasing and reflecting to the media.

In Turkey, where the male-dominant expressions structured, media's approach to woman is a lot like the patriarchal attitude of men, who knows what is best and what is wrong for the women (Akbulut, 2004: 158).

In media, the factor of woman has been attributed meanings such as housewife, good mother-good wife, selfless, sexual meta, powerless, malignant, ambitious business woman. The problem of inaccurate and deficient representation of woman in media is not a specific problem for our country only, but a universal one. Usage of the woman image with its femininity aspect, pure womanlike features such as good-wife, devoted mother, in other words the exploitation of woman as a meta should be changed erewhile and we should see women with their successes in culture, art, sports, politics areas instead of the sexy women or oppressed women images.

When we look through reaching wide audience advertisements, usually reflect the opinion of social trends; we can say, Clichés of women in such messages emphasizes the social role of women in society. Advertisements in media and woman relations have been looked on two key points. First, the women how look to woman; second, the men how look to woman (Tosun, 2006: 88). In order to be successful in reaching the objectives of advertising messages, in which a character must meet the norms of society. For this, the attitude toward women and women should be evaluated in view of the norms of society. Until recently, women who were in the media had three different identities: One of them was a perfect spouse who is adorned with the traditional standard of judgments, which is required in order to reach the value judgments of society for the success of the advertisement messages. The second is a mom, who devoted herself to her children and the third one is an attractive women who is strong with her feminine features.

Today, in order to consummate the "woman" on the advertisements, a new identity undertaking has been performed. With the increase in education level and dense appearance of women in business life enabled a workingwoman image on advertisements. In other words, the new woman of the advertisement is, on one hand, a good spouse and a mother and on the other hand a successful businesswoman and an attractive beautiful woman.

The most traditional way to use a man as a sexual object in advertisements is the direct usage of woman as a sex object. They are the objects of beholding for both themselves and for men. Even there is a saying that the publicists know very well: 
"Men want to see a beautiful woman. Women also want to see a beautiful woman" (Bat1, 2006: 9). The image of woman in media is an image, which is frequently used, especially in advertisements, which appeal to purchasing power of society. When the usage of woman image is observed in media-woman relation; distinctive points like women's observation of women or men's observation of women (Sullam, 2004: 152). This situation is corroborative of Batı's assignation above. Even though it is known that both women and men favor the image of woman in advertisements, mostly it is determined by the men's viewpoint for women. As a result of this, even though there is an expected positive feedback, occasionally it might cause a negative answer or a bad reaction; because no matter what, the signification of society is directly proportional to its culture.

It is possible to group the images of woman that are frequently determined by men in the advertisement tools in two groups:

1. The ones regarding the role of women at home: Here, woman is a spouse or a mother who is kind, diligent and has a high sense of mission and a hospitable landlady.

2. The ones regarding the sexuality of woman: Here, a woman is highly feminine, giddy, erotic, half naked, but an unattainable lover (Elden and Ulukök, 2004: 136).

In another point of view, it can be stated that women have importance for capitalist systems for two reasons. First is the woman as a consumer and the reasons for this are: the home management task is in the responsibility of woman, women's no limitations on shopping, their big shopping appetite, being unable to be rational on shopping and being easily affected. The second importance that the women have for capitalism is to be the tool for increasing the men's consumption by using the image of women in advertisements (Barokas, 1994: 22). Usage of a woman's body in advertisements is seen as a cheap trick, but still the marketing experts prefer this to the creation of rational ways that are in favor of the product. This process in advertisements is simple. Attractive bodies first attract then build up desire and this desire is inclined to the product. The woman body is presented as the trophy of consumption.

Through the advertisements, the definition of beauty is changed, physically attractive women are cherished and women who have inner beauty, but physically lack the effectiveness of a model are excluded. In the advertisements that very beautiful women appear on, external and temporary beauty is emphasized rather than the product itself. The sense of beauty that emerges as the foundation of beauty 
and slimness is under the sway of bodies which are transformed into an image, a thing that exists to be seen, to be watched (Gürel, 2004: 213). Along with this, the sense of beauty is totally changing, the woman will not feel beautiful no matter what she does. This brings a lot of problems with itself.

The woman, who is inclined to consumption through advertisements, is being consumed at the same time through advertisements. Because the woman, who is presented as attractive, sexy and isolated from all of her defects, both inclines her target group to consumption and becomes the object of the advertisement (Aksoy and İcil, 2007: 89-90). As a result, the women incline to consumption to be beautiful, slim, and attractive and are consumers at the same time. Moreover, the women are made objects by presented as sexy, attractive in these advertisements. In this case the woman is consumed as a watched-object. Women are both the consumer and the consumed of the advertisement that uses the image of woman.

\section{Research}

\subsection{The Purpose and Scope of the Research}

Advertisement is a great instrument that reflects the society's culture and aptitude; because in order to be successful they need to be suitable for the society's culture and norms. This situation gives us important clues about the existing genders mainstreaming of women who are the consuming and consumed object of advertisement. Women's image, the place and roles of women in society is than better understood via the status of woman in outdoor media. The roles of a woman in society changes and develops by time. For this, culture has a big importance. Societies determine their gender mainstreaming according to their culture and experiences. The aim of this study is to analyze the woman figure in Turkish culture, gender mainstreaming of women, and the roles of women in outdoor advertising. In our days, the outstanding roles for women are a good wife, mother, hardworking successful women, and classy and attractive women in Turkey as well as worldwide. These roles are composed depending on how women want to see themselves parallel to how men want to see women.

In this study, the image of women in outdoor advertising in Turkey is investigated with a semiotic analysis and the gender mainstreaming and roles of women are analyzed. During the analysis, different roles of women in different ads from different sectors are discussed. Some of these ads address directly to women and some of them address to general needs. That is how the women image that is wants to be seen by men and women and women in different roles are analyzed. 


\subsection{Limitations of the Research}

In this study, where the semiotic analysis of woman image in advertisements is done, several exceptional outdoor advertisings were photo shot in various neighborhoods in Istanbul. Then from these advertisements, at least two samples were kept from similar sectors to increase the sector variability. During the election, serious attention was paid to in order to have samples of ads with women in different roles in different sectors. Yet another factor used in the election is the target customer of the product advertised. Again for the election, attention paid for selecting advertisements that address women only and both men and women.

The examples used in the analysis are composed of companies that carry outdoor advertisings of products such as cosmetics, hygiene products, communication products, personal products, and food products. Again another element that affected the selection process is the role of women in advertisements. In this election, the roles of women as a mother, the active roles of women in business, and women who are classy and attractive have been taken into account. The research has been done in various neighbors of Istanbul and the advertisements chosen are the ads that are the same all over Istanbul. As one of the most advanced and most prosperous province of Turkey, Istanbul embraces different religions, cultures and people with differentsocio-economic status at the same time. Considering women's gender mainstreaming and role in the society, this is the reason why Istanbul is chosen for the analysis of this research.

\subsection{Method of the Research}

In this research, while the semiotic analysis of outdoor advertisements is made, the interpretation of visual and linguistic massage of the advertisement will be evaluated together. The factors that Berger underlined which are emphasized in advertisement analysis will be generally evaluated and Saussure's analysis of sign signifier-signified distinction will be used. According to Barthes, there are three ways in reaching to interpretation. First is myth aspect second is symbol aspect and the third one is metaphor aspect. Mostly, the traces of these three aspects can be observed in advertisement messages. In Barthes' first level interpretation, sign system and in his second level, culture system is mounted in the value system. 
In analysis section of this study, lastly, Barthes' analysis of denotation connotation differentiation will be utilized and an analysis will be made by using second interpretation level. The advertisements in this research analyzes with the culture they belong.

\subsection{Findings of Research}

\subsubsection{Avon}

Brand name: Avon Cosmetics

Signifiers: Visual Text: shining red lips and red lipsticks with a famous woman (Reese Witherspoon) who is wearing whites sitting comfortable on a red platform. Written Text: (motto) Vibrant colors? Sparkles? I won't give up either, (product name) New shine attract lipstick, (brand name and contact) Avon, 08002114481/avon.com.tr

Significants: purity, cleanliness, stability, passion, love, vitality, dynamism, modernism

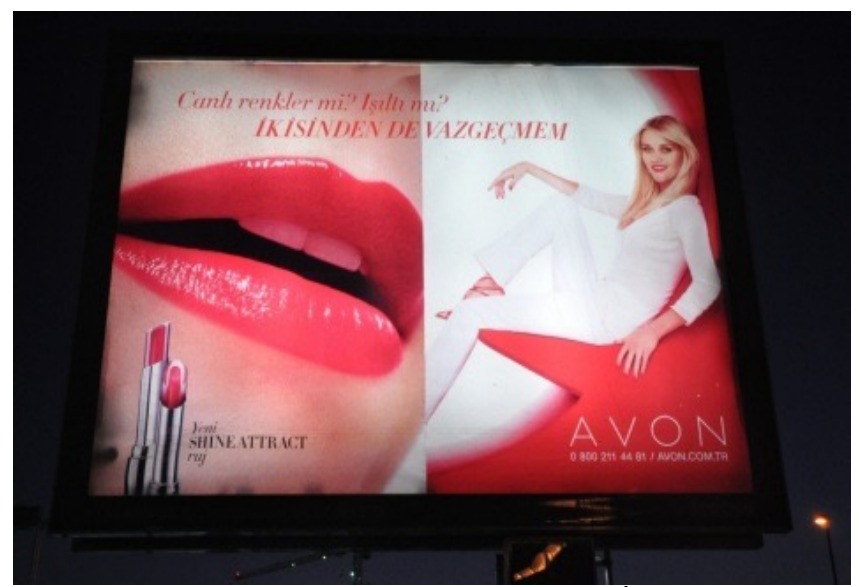

Figure.1 Avon (Personal Photoshoot, Beşiktaş, İstanbul, 2011)

Analysis: Looking at the overall appearance of the ad highlights the use of red and white colors. White color refers to purity, cleanliness, and stability and red color 
refers to passion, love, vitality, and dynamism. The use of these two colors puts these two situations interwoven in this advertisement. Red and radiant lips with small gap between take up almost half of the left side of the ad and attract the attention. The reminiscent of the lips is sex appeal and attractiveness. Lips that seem like whispering something to the audience stand before the figure of woman. The product is at the bottom of the lips and this provides a transition between the lips of women. The female figure is used for the other half of the ad. Here, a famous woman with a pure beauty is used. The woman in the ad with white cloths all over represents purity, cleanliness, and modernism with her plain appearance. The woman in the ad is a working, self-confident, and comfortable woman. The advertising product conveys a message to the audience; that is the product will create lustful, lovely, comfortable, vital, and self- confident woman. As shown herein, the lipstick is complementary to woman. The text in the ad 'Vibrant colors? Sparkles? I won't give up either' indicates the color used. This text also matches with the image of the woman. With bright yellow hair and a white dress the woman shines here as a star. The red lipstick used on her lips and the red lips next to her glint and take attention with their vibrant colors. The woman who says she won't give up either implies that she gained charm and vitality thanks to the product.

The target audiences in this ad are women who are modern, active in business life, want to show them, and wish to draw attention with their purity and a woman who has these skills is presented. Finally, at the bottom right corner of the ad, brand name and contact info are given in order for the target audience to be able to reach the product.

\subsubsection{Elseve}

Brand name: Loreal Elseve

Signifiers: Visual Text: woman figure Jennifer Lopez look over her shoulder; product bottles

Written Text: Revolution of Argen - Without Argen, hair stops growing; Jennifer Lopez's choice; Without Argen hair stops growing; 3-effect: root, stem, tip, hair loss is reduced considerably and it's new; Loreal Paris

Significants: power, passion, beauty, attractiveness, feminity 


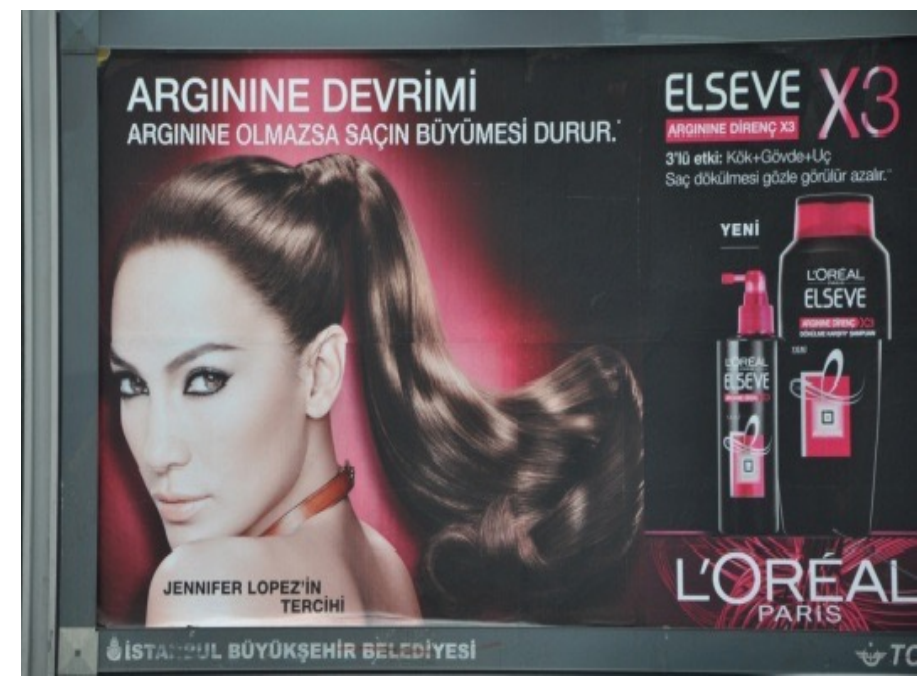

Figure 2. Elseve (Personal Photoshoot, Kadıköy, İstanbul, 2011)

Analysis:

Looking at the overall appearance of this ad with the colors black and fuchsia color of the product is being used. At a large portion of the ad a female figure is given; the product is placed on the right side; and in between a lot of text is used. The female figure used here is Jennifer Lopez who is known as a famous and attractive woman. Lopez, with her attractive look over her shoulder, looking naked with her bare shoulders, her eye catching make-up that shows her as a wild animal, and with her long, gathered, and shiny hair draws attention. Her black eye make-up shows the power and passion. With her manner and appearance, Lopez looks like a wild lynx. Under the visual text, there is a text that says "Jennifer Lopez's choice". This means that because of her beauty, attractiveness, and long hair, Jennifer Lopez chose this product. The main text of the ad is "Revolution of Argen - Without Argen, hair stops growing". This text highlights that Argen is a revolution and a great innovation. With the claim "Without Argen hair stops growing", the fear is injected to consumer because for centuries long hair is a symbol for femininity. A not 
growing hair is a nightmare for most of the women. This situation is somewhat related to the trends. Shortly before, women with short hair were found modern and drew attention, now returning to past brought back the former importance of long hair. On the right side of the ad, the product packaging and characteristics of the product are given. These are "3-effect: root, stem, tip, hair loss is reduced considerably and it's new". Today, with the development of the technology we have learned a lot and they can be more easily reached; this is highlighted in the ads. As we know from shampoo commercials, nutrition from root to tip is important; this is also emphasized here. It is no longer enough just to feed the body of the hair; it is emphasized in this ad that feeding the roots increases the hair growth and feeding the tips eliminates the broken ends problem. At the bottom right corner the brand "Loreal Paris" is given and the perception of quality is injected to customers by emphasizing the brand's origin is Europe. This product's target audiences are women; these women want to be sexy and attractive. For this it can be seen that these are women who take care of their long hair and try to be trendy.

\title{
2.4.3. Doritos/ Fritos Shots
}

\author{
Brand name: Doritos / Fritos Shots
}

Signifiers: Visual Text: famous model/actress Megan Fox wearing red dress standing in front of a dark blue curtain background and about to ear chips; brand logotype

Written Text: motto: With the most fashionable chips of the year, we cheer up whoever comes through; product name: fritos shots

Significants: sexuality, cheering, taste, appeal, beauty 


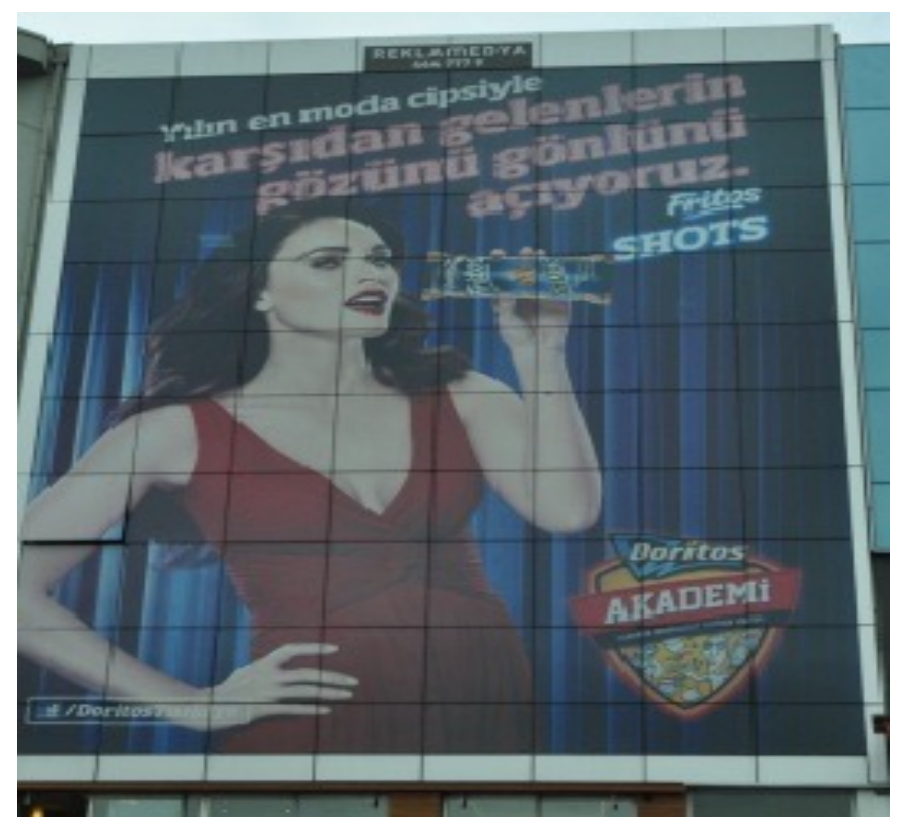

Figure 3. Doritos/ Fritos Shots (Personal Photoshoot, Kadıköy, İstanbul, 2012)

Analysis:

Looking at the overall appearance of this ad, a large portion of the ad is covered with model/actress Megan Fox. In front of a dark blue curtain background, Megan Fox comes forward with her red dress. In the visual text, Fox drawing attention with her stylish low-cut dress, reminds sexuality. With her one hand on her waist, the other hand holds the product, she seems like she is about to eat the chips. To use a model as the consumer of chips, a high calorie product, creates a contrast display and distorts the perception. The text of the ad says "With the most fashionable chips of the year, we cheer up whoever comes through". By saying whoever comes through, the ad shows that it designed only for outdoor advertising.

In this ad, it is Megan Fox who cheers people up and she stands before the product. The other visual element of this ad is the logo of the product at lower right corner; this provides the permanence of product in mind. Use of a pretty big logo brings the 
product a little to the front. Another written text of the ad is at the lower left corner, the product's Facebook address, because Facebook is one the most famous media channels. Female image in this ad is a famous, prominent, sexually evoking, and beautiful woman. Ad's target audiences are both men and women, but we cannot ignore that the items used in the ad will appeal more to men. In this advertisement, items that men would like to see more intensively are used.

\subsubsection{Kotex}

Brand name: Kotex

Signifiers: Visual Text: 1. Woman standing with a pilot costume, 2 . Woman standing with white dress, 3 . Woman sitting on stairs with a red trousers and white blouse.

Written Text: New Kotex; Don't afraid to change; Use new kotex for better; Kotex ultra dry\&soft

Significants: cheerfulness, romance, power, purity, sterility, innocence and positivity, confidence, attractiveness, natural, pure, elegance, comfortable, casual and stylish. 

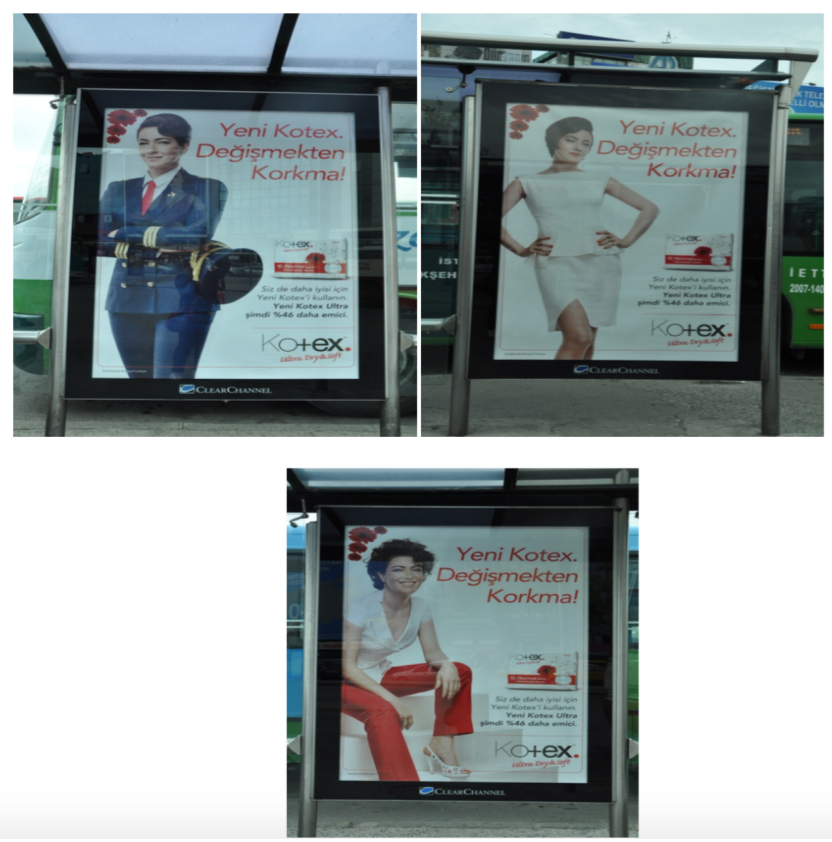

Figure 4. Kotex (Personal Photoshoot, Kadıköy, İstanbul, 2012)

Analysis:

It is better to analyze this three advertisement together because they are all designed together, their written texts and the woman in this advertisements are same. The only different thing in this advertisement is role of the woman in these advertisements. When analyzed the overall appearance of this advertisement it is obvious that the colors used in these advertisements are compatible with the colors of the product package, these colors are red and white. Red is hottest of the warm colors and it means energy, passion, love, cheerfulness, romance, power. White is the brightest color and it signify peace, purity, sterility, innocence and positivity. All of these meanings are effective on these advertisements.

The first written text of this advertisement is "New Kotex". This text shows that this brand make some changes on this product probably with a new technology. "Don't afraid to change" text indicated two things. One of them tells the consumers that if you are using another product don't afraid to try this product. The other 
means don't afraid to change yourself your role of gender mainstreaming. The last text of this advertisement is "Use new kotex for better". This text refers to the other texts and makes a comparison with the same products of different brands. The difference between these advertisements is appearance and role of the women image in them. Famous woman, Meltem Cumbul has different roles in these three ads. In the first advertisement, Meltem Cumbul was standing with a pilot costume. It is not a usual thing that to see woman pilots. This visual text refers to the "don't afraid to change" text. It shows that this product is for confident, poised woman who is not afraid to change her role in society. The role of the woman in this advertisement is, confident, poised, modern women also active in business life. In the second advertisement, Meltem Cumbul is standing with a white dress. She has a professional look in this advertisement. The color white refers to purity, cleanness, sterility and it also refers to product with it's meaning. The role of the woman in this advertisement is an attractive, natural, pure, elegance woman that is also active in business and modern life. In the third advertisement Meltem Cumbul is sitting on stairs with a casual, modern look. Both red and white are used in her dress. The role of women in this advertisement is a comfortable, casual and stylish woman who is also active in business life. All of these woman images in these advertisements are active in business life and it is new role of the woman in society. Therefore don't afraid to change experession refers also to don't afraid to be in business life and your new role. At the end the role of women in this ad is the image of a businesswoman that woman would like to see. And the targets of these advertisements are women.

\subsubsection{Nutella}

Brand name: Nutella

Signifiers: Visual Text: Mother standing and looking at her child eating Nutella with excitement Written Text: excitement in the morning

Significants: exaltation, happiness, taste, family, excitement. 


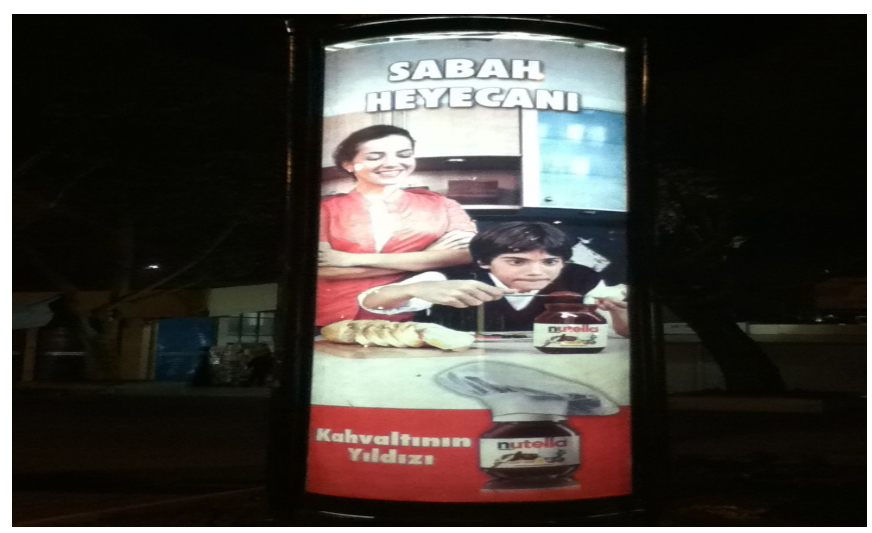

Figure 5. Nutella (Personal Photoshoot, Üsküdar, İstanbul, 2011)

Analysis:

If we check this advertisements general atmosphere we will directly focus on a mother and a kid in the kitchen. Generally the visual stuffs remarkable on the advertisements. The first visual stuff is the kid eating Nutella excitedly on the table he second visual stuff is the women who has a happy face cause of the kid. And she looks at the kid with a lovely smiling. The woman looks very happy because of the kid happiness, we could easily understand that her half taking sit half standing around, excited, hectic acts.

On this ad," excitement in the morning" used as the slogan. The excitement herein actually separated from the mother and child. There are 2 different excitement one of them the child's mother excited of to make ready her child to the school, child excited to have Nutella and to be on time at the school. Reconciling these two thrills of mother and child were transferred to the slogan. Although the child who eats nutella so much excitement all the people that even though the target group of children the love of chocolate, the audience for this ads for this product in children and mothers who makes the shopping of the house. The role of the mother image used in advertising and a good mother who takes care of her children, a housewife as well formed. Children of mothers taking this product in this ad, families are given the message and therefore would themselves happy to buying Nutella. 


\subsubsection{Penti}

Brand name: Penti

Signifiers: Visual Text: woman wearing bikini holding her child with her arm; penti.com

Written Text: Penti, All beaches are Penti on this summer, online shopping

Significants: mother image, attractiveness, beauty, self-confidence.

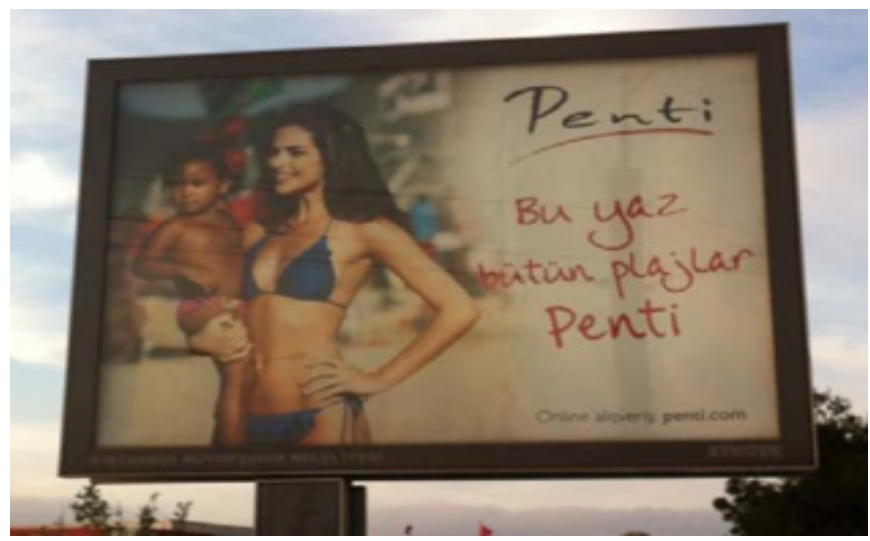

Figure 6. Penti (Personal Photoshoot, Kadıköy, İstanbul, 2012)

Analysis:

Soft colour combination montage has been seen in the general view of this advertisement. The visual text of the advertisement is combined of a mother and her child on her arms who are, we suppose, on the beach. The woman image in here is an attractive woman who is at mother role and has a beautiful physical. One of the arms of the woman is on her waist; the other one hugs her child. Both the woman's confidence to herself, her strong standing, her perfect physical and her motherhood role comes out by holding her child with her arm.

The woman image in this advertisement is in a view that refines the mother role at the present on our society. . The woman's appearance, standing and showing of her perfect body with her bikinis both gives the message to the mothers on other nations that "You can both be a mother and be seen perfect" and highlights that the 
self-confidence of wearing bikinis is totally up to mothers. . The script of the advertisement focuses on the message:" All beaches are Penti on this summer". The script attracts attention that the brand Penti, generally known as a sock brand, is now on a new field and fabricates beachproducts. Moreover, the target customer number has been broadened by the advertisement. Not only young mothers but also the whole women who are mother have been brought to the possible target customers when analysed with the visual text of the advertisement.

One another script of the advertisement is the web address of the product's online shopping. Nowadays, people have dramatically started shopping online and this situation has become a new trend with the help of developments and increasing usage in technology. People reach easily the product which they see in advertisements whenever they want and get it with the given script. The target customer of the advertisement is women and the woman image on this advertisement is on the role that woman want to see themselves as.

Though the woman on the text does not totally mesh with the woman on our daily society, this image is on a perfect view which a woman wants to turn into. While the woman on our society is on the ambition to be successful both at her family life and her daily life, on the other hand she wants to be seen perfect. The woman figure who takes attention with her perfect physical and confident standing, thought, has a child at a little age, strengthens this situation.

\section{Discussion and Conclusion}

The usage of women in advertisements dates back to old times. The biggest reason of using woman as an element of the advertisement is woman being the real consumer. By their social role, the target group of many products like, food, furniture, and clothing are women. As an individual that is responsible of the role of kind mother and good wife, the woman shops for the house and her family and in beautiful women role, she shops for cosmetics and beauty products. As a result of all of these, the woman, who is the target group and the consumer of advertisements, want to see the gender reflection in advertisements. Usually, the women in the advertisements are in the role that the women themselves want to see them in.

This research analyzes woman image on outdoor advertisements by semiotic analyses of Barthes, Saussure and Berger's analyzing theories. This research presents situation of woman image in 2011, 2012 outdoor advertisements in İstanbul. I shot photos of advertisements from different neighborhoods of all over Istanbul. After taking photos of the outdoor advertisements, the selection is made by samples of advertisements with women in different roles in different sectors. In this 
election, the roles of women as a mother, the active roles of women in business, and women who are classy and attractive have been taken.

As mentioned before other election element for this research is different companies from different sectors. The companies chosen for food sector are Doritos and Nutella. Avon and Elseve chosen for beauty product sector. At the end for individual use products Penti and Kotex chosen for analyze. These companies and sectors has different targets, some of them has targets only woman some of them targets both woman and man.

In this research last election element is the role of woman on outdoor advertisements. In these advertisements woman have different roles like a good mother, a woman active in business life, comfortable woman who cares herself and beautiful attractive woman. In Nutella advertisement o good mother draw attention. In beauty product advertisement like Elseve and Avon beautiful, attractive and polished woman are situated. In the other food products like Doritos sexually attractive famous woman take place. Kotex advertisements use different woman images on their advertisement, one of these roles is modern woman who is active in business life the other is woman who has modern look. She has a professional look but she can also be a good mother of a good wife.

This research presents the difference between target groups and observers in outdoor advertisements. There are two different observers of outdoor advertisements. One of them is the woman image that woman wants to see themselves the other is the woman image that man how wants to see woman. For this situation this research shows that women want to see themselves as a beautiful, self-confident, strong and active in business life. The advertisements of products that are only for woman provide this result. In the other hand man wants to see woman image as beautiful and attractive. Woman image is changing day by day as gender mainstreaming. Also the roles of woman image changing everyday like the woman image on advertisements change. As seen in Kotex advertisement nowadays woman can be even a pilot and it is not something that we have to afraid of. The new woman image in gender mainstreaming and also advertisements is strong woman who can make decisions for herself, beautiful and well groomed woman that can also be a good mother and wife and self-confident attractive woman who is also active in business life.

This analyzes shows that gender mainstreaming and woman image changes in social life and it also affect advertisements. Woman affects and affected by advertisements because woman is the most visible image on all kinds of advertisements because woman is both receiver of the products and advertisements and constituent of advertisements. In gender mainstreaming, woman is the one that usually goes shopping and decides what to buy. By the changes of gender mainstreaming this situation is changing. But now woman image is more visible 
than man image on outdoor advertisements. This situation will probably change in years by the way people and gender mainstreaming changes.

As a result of this research outdoor advertisements are effective way to change woman image and show woman image by the way both woman and man wants to see and it is affected by gender mainstreaming. Also outdoor advertisements are affective for analyzing woman image's situation by gender mainstreaming. In this day and time beautiful, attractive, strong, intelligent woman image and their housewife and businesswoman roles stand out on gender mainstreaming. It is also shows parallelism with their way to seem and roles on outdoor advertisements. In analyzed advertisements, the woman image that both man and woman want to see, attracts attention. In the work of analysis, it is precipitated that there is both the woman image, which is influenced by the roles of woman today and the perfected image that the woman wants to see herself in, on outdoor advertisements. As a result of this, it can be stated that the women are both the subjects and objects of outdoor advertisements.

\section{KAYNAKLAR}

Akbulut, N. T., (2004). Türk Televizyonunda Kadın Söylemi, Kadın Çalışmalarında Disiplinler Arası Buluşma, Vol. 2, Yeditepe University, Faculty of Fine Arts, First Edition, İstanbul, pp. 157-162.

Aksoy, S. and İcil, A., (2007). Reklamlar Aracllğgyla Tüketen ve Tüketilen Bir Nesne Olarak Kadın Sunumuna Göstergebilimsel Yaklaşım, Medya Okumaları, Comp: Ö. Yılmazkol, Ankara: Nobel Yayın Dağıtım, pp. 85-105.

Barokas, S. K., (1994). Reklam ve Kadin, İstanbul: Türkiye Gazeteciler Cemiyeti Yayınları.

Batı, U., (2006). Tüketilen Kadın Bedeni: Kadın Bedeninin Parfüm Reklamlarındaki Görünümünün Göstergebilimsel Çözümlemesi, Journal of EDAM, Retrieved January 6, 2012, from http://www.ugurbati.com/makale/T\%DCKET\%DDLEN\%20KADIN\%20BEDEN\% DD-MAKALE.pdf

Bora, A. and Üstün, İ., (2005). Sicak Aile Ortamı- Demokratikleşme Sürecinde Kadin ve Erkekler, İstanbul: Tesev Yayınları. 
Elden, M. and Ulukök, Ö., (2004). Televizyon Reklamlarında Çalışan Kadının Sunumu, Kadın Çalışmalarında Disiplinler Arası Buluşma, Vol. 2, Yeditepe University, Instute of Fine Arts, First Edition, İstanbul, pp 135-142.

Gürel, E., (2004). Barbie Bebek İzdüşümünde Kadın Kimliğinin Analizi, Kadın Çalışmalarında Disiplinler Arası Buluşma, Vol. 2, Yeditepe University, Instute of Fine Arts, First Edition, İstanbul, pp. 209-216.

Sullam, B., (2004). Jinekomedya, Kadın Çalışmalarında Disiplinler Arası Buluşma, Vol. 2, Yeditepe University, Instute of Fine Arts, First Editon, İstanbul, pp. 151-155.

Tosun, N. B., (2006). "Reklam Aracı Olarak Kadın”, Kadın Çalışmaları Dergisi, Year: 1, Issue: 1, İstanbul, pp 88-93.

Üner, S., (2008). Toplumsal Cinsiyet Eşitliği, Ankara: T.C. Başbakanlık Kadın Statüsü Genel Müdürlüğü. 